BULLETIN OF PNRPU. GEOLOGY. OIL \& GAS ENGINEERING \& MINING

ВЕСТНИК ПНИПУ. ГЕОЛОГИЯ. НЕФТЕГАЗОВОЕ И ГОРНОЕ ДЕЛО

ISSN 2224-9923

Volume/ Toм 16 №1 2017

http://vestnik.pstu.ru/geo/

УДК 553.611

Article / Статья

(C) PNRPU / ПНИПУ, 2017

\title{
MASS CHANGE OF BOUND WATER IN CLAYS UNDER COMPRESSION
}

\author{
V.V. Seredin, T.Iu. Parshina
}

Perm State National Research University (15 Bukireva st., Perm, 614068, Russian Federation)

\section{ИЗМЕНЕНИЕ МАСС СВЯЗАННОЙ ВОДЫ В ГЛИНАХ ПРИ СЖАТИИ}

\section{В.В. Середин, Т.Ю. Паршина}

Пермский государственный национальный исследовательский университет (614068, Россия, г. Пермь, ул. Букирева, 15)

Received / Получена: 10.11.2016. Accepted / Принята: 03.03.2017. Published / Опубликована: 31.03.2017

Key words:

montmorillonite, kaolinite, clay, pressure, mass loss, thermal analysis, $\mathrm{x}$-ray phase analysis, correlation matrix, regression analysis, colloid, mineral.

\begin{abstract}
In general, reliability of industrial and civil units is determined by strength and deformation properties of foundation soils of structures. On the one hand, calculated values of mechanical properties largely depend on technogenic load on a ground base, and on the other hand, on content of bound water in soils, especially clays. Many Russian and foreign scientists were engaged in evaluation of bound water in clays. Their works describe an effect of mineral composition, initial moisture and composition of clay exchange cations on thermal dehydration of bound water. It was found that the smaller the size of clay particles, the sharper dehydration curves diverge in a high-temperature area. The conclusion is drawn that there is no significant discontinuity in values of energy, corresponded to active centers on basal facies and crystal chips. The paper presents results of studies of change of properties of bound water in clays under influence of high temperatures and pressures. To researchers' mind, during compaction of clays saturated with water, free water of large pores is first to be removed, then under 1-3 MPa load osmotic water, and under pressure of more than $10 \mathrm{MPa}$ structured hydrate layers begin to be removed. Closest to a hard surface water layers, which determine moisture content in clays, are not squeezed out at tens of megapascals, when monolayers at loads of hundreds of megapascals. As a result of studies conducted it was experimentally established that in kaolinite and montmorillonite clays content of film and absorbed water of the colloid, as well as surface water and water of hydroxyl groups of minerals varies with change in pressure magnitude. It is established that studied parameters influence total water loss differently, which is confirmed by various mathematical models. However, in all cases, except for montmorillonite subjected to pressure of more than $1000 \mathrm{MPa}$, the most important factor determining the overall loss of water mass is adsorbed water of minerals.
\end{abstract}

Ключевые слова: монтмориллонит, каолинит, глина, давление, потеря массы, термический анализ, рентгенофазовый анализ, корреляционная матрица, регрессионный анализ, коллоид, минерал.

\begin{abstract}
Надежность промышленных и гражданских объектов определяется в основном прочностными и деформационными свойствами грунтов оснований сооружений. Расчетные значения механических свойств, с одной стороны, во многом зависят от техногенной нагрузки на грунтовое основание, а с другой - от содержания в грунтах, особенно в глинистых, связанной воды. Оценкой связанной воды в глинах занимались многие российские и зарубежные ученые. В их работах описано влияние минерального состава, начальной влажности и состава обменных катионов глин на термическую дегидратацию связанной воды. Приведены данные о влиянии размера частиц на вид кривых дегидратации. Выявлено, что чем меньше размер глинистых частиц, тем резче кривые дегидратации расходятся в области высоких температур. Сделан вывод о том, что в значениях энергий, соответствующих активным центрам на базальных гранях и на сколах кристаллов, нет большого разрыва. Представлены результаты исследований по изменению свойств связанной воды в глинах под действием высоких температур и давлений. По мнению исследователей, при уплотнении водонасыщенных глин в первую очередь удаляется свободная вода крупных пор, затем при нагрузках 1-3 МПа осмотическая вода, а при давлении более 10 МПа начинается удаление структурированных гидратных слоев. Ближайшие к твердой поверхности слои воды, определяющие влажность глин, не отжимаются при нагрузках в десятки мегапаскалей, а монослои - при нагрузках в сотни мегапаскалей. В результате проведенных исследований экспериментально установлено, что в каолинитовых и монтмориллонитовых глинах содержание рыхлосвязанной и прочносвязанной вод коллоида, а также воды поверхности и гидроксильных групп минералов изменяется в зависимости от величины давления. Установлено, что в образовании общей потери масс воды исследуемые показатели принимают различное участие, что подтверждают различные математические модели. Однако во всех случаях, кроме монтмориллонита, подверженного давлению более 1000 МПа, наиболее существенным фактором, определяющим общую потерю масс воды, является прочносвязанная вода минералов.
\end{abstract}

Valerii V. Seredin (Author ID in Scopus: 56974744000) - Professor, Doctor of Geological and Mineralogical Sciences, Head of the Geological Engineering Department (tel.: +007 34223964 39, e-mail: seredin@nedra.perm.ru).

Tatiana Iu. Parshina - PhD student at the Geological Engineering Department (tel.: +007 34223964 39, e-mail: seredin@nedra.perm.ru)

Середин Валерий Викторович - профессор, доктор геолого-минералогических наук, заведующий кафедрой инженерной геологии (тел.: +007 3422396439 , e-mail: seredin@nedra.perm.ru).

Паршина Татьяна Юрьевна - аспирант кафедры инженерной геологии (тел.: +007 34223964 39, e-mail: seredin@nedra.perm.ru). 


\section{Introduction}

Reliability of industrial and civil facilities is determined mainly by strength and deformation properties of soils that compose base of structures. On the one hand calculated values of mechanical properties of soils depend on artificial load on soil base [1], on the other hand they depend on content of bound water in soils (especially clayish) [2]. Many Russian [3-5] and foreign scientists [7-11] were engaged in evaluation of bound water in clays. Several works [5-6] describe an effect of mineral composition, initial moisture and composition of clay exchange cations on thermal dehydration of bound water. Data on effect of particle size on shape of dehydration curves are given in [7, 12]. It was found that the smaller size of clay particles, the sharper dehydration curves diverge in hightemperature area. The conclusion is drawn that there is no significant discontinuity in values of energy, corresponded to active centers on basal facies and crystal chips.

The papers [3-11] present results of studies of change of properties of bound water in clays under influence of high temperatures and pressures. To researchers' mind, during compaction of clays saturated with water, free water of large pores is first to be removed, then under 1-3 MPa load osmotic water, and under pressure of more than $10 \mathrm{MPa}$ structured hydrate layers begin to be removed. According to data of authors [4-11], water layers closest to hard surface that determine moisture of clays, are not squeezed out under loads of tens of megapascals, and monolayers at loads of hundreds of megapascals.

However, despite the high scientific and practical value of the problem, there are not enough experimental studies. Comparative analysis of compression resistance of clays with different mineral and structural type could be a field of especial interest.

This paper describes changes in mass of bound water in kaolinite and montmorillonite clays under load.

A method for preparation of samples and determination of loss of bound water mass in clays is given in [5-6].

Following types of water mass loss are considered, \%: film water $-\mathrm{MS}_{\mathrm{FW}}$, adsorbed water in a colloid - $\mathrm{MS}_{\mathrm{AWC}}$, adsorbed water in a mineral $\mathrm{MS}_{\mathrm{AWM}}$, hydroxyl groups in a mineral $-\mathrm{MS}_{\mathrm{HGM}}$, recrystallization of minerals $-\mathrm{MS}_{\mathrm{RCM}}$ and total loss of bound water mass $-\mathrm{MS}_{\mathrm{T}}$. Normal stresses $\mathrm{S}_{\mathrm{n}}$, $\mathrm{MPa}$ is used as a load parameter. During processing of experimental data, statistical analysis was used.

At the first stage, influence of pressure on change in mass of bound water in clays was studied. Mean values were estimated by $t$ criterion for kaolinite and montmorillonite. A difference in mean values is considered statistically significant if $t_{p}>t_{t}$. Comparison of mean values of studied parameters is given in Table 1. In this case estimation $t_{t}=1.98$ is carried at $n_{1}=n_{2}=96$ and degree of significance $(\alpha=0.05)$. In addition, during statistical analysis of data studied, a correlation analysis was used (Table 2). The comparison showed that for the same loads, mean losses for certain water categories for kaolinite and montmorillonite are statistically different.

Table 1

Comparison of mean values of clay parameters

\begin{tabular}{|c|c|c|c|c|}
\hline \multirow{2}{*}{ Parameter } & \multicolumn{2}{|c|}{$\begin{array}{c}\text { Mean values and } \\
\text { variance of parameters }\end{array}$} & \multicolumn{2}{c|}{ Student's coefficient } \\
\cline { 2 - 4 } & kaolitine & $\begin{array}{c}\text { montmo- } \\
\text { rillonite }\end{array}$ & $\begin{array}{c}t_{p} \\
\text { calculated }\end{array}$ & $t_{t}$ critical \\
\hline $\mathrm{S}_{\mathrm{n}}, \mathrm{MPa}$ & $665.0 \pm 735.0$ & $665.0 \pm 735.0$ & $0.0000<1.98$ \\
\hline $\mathrm{MS}_{\mathrm{FW}}, \%$ & $2.8 \pm 0.9$ & $5.1 \pm 0.8$ & $18.2857>1.98$ \\
\hline $\mathrm{MS}_{\mathrm{AWC}}, \%$ & $0.40 \pm 0.22$ & $0.96 \pm 0.24$ & $16.5711>1.98$ \\
\hline $\mathrm{MS}_{\mathrm{AWM}}, \%$ & $7.5 \pm 1.3$ & $4.6 \pm 1.9$ & $11.5881>1.98$ \\
\hline $\mathrm{MS}_{\mathrm{HGM}}, \%$ & $1.46 \pm 0.81$ & $2.98 \pm 1.07$ & $11.0205>1.98$ \\
\hline $\mathrm{MS}_{\mathrm{RCM}}, \%$ & $0.68 \pm 0.47$ & - & \multicolumn{2}{|c}{-} \\
\hline $\mathrm{MS}_{\mathrm{T}}, \%$ & $12.8 \pm 2.9$ & $13.7 \pm 3.4$ & $2.1187>1.98$ \\
\hline
\end{tabular}

At the same time, a statistical difference for total water mass losses was also obtained, but not so significant (see Table 1). This indicates that when values of $S_{n}$ are in the interval of $0-2000 \mathrm{MPa}$ losses in different types of water for kaolinite and montmorillonite occur according to different scenarios. In order to look over dynamics of changes in water loss parameters, it is needed to construct functions of change in water mass losses with increase in $S_{n}$ values. Quantitatively these changes are estimated by calculations of values of $r$. In addition, it is needed to find values of $r$ between analyzed types of water losses. Changes in values of $\mathrm{MS}_{\mathrm{FW}}$ versus $\mathrm{S}_{\mathrm{n}}$ are shown in Fig. 1, a. 

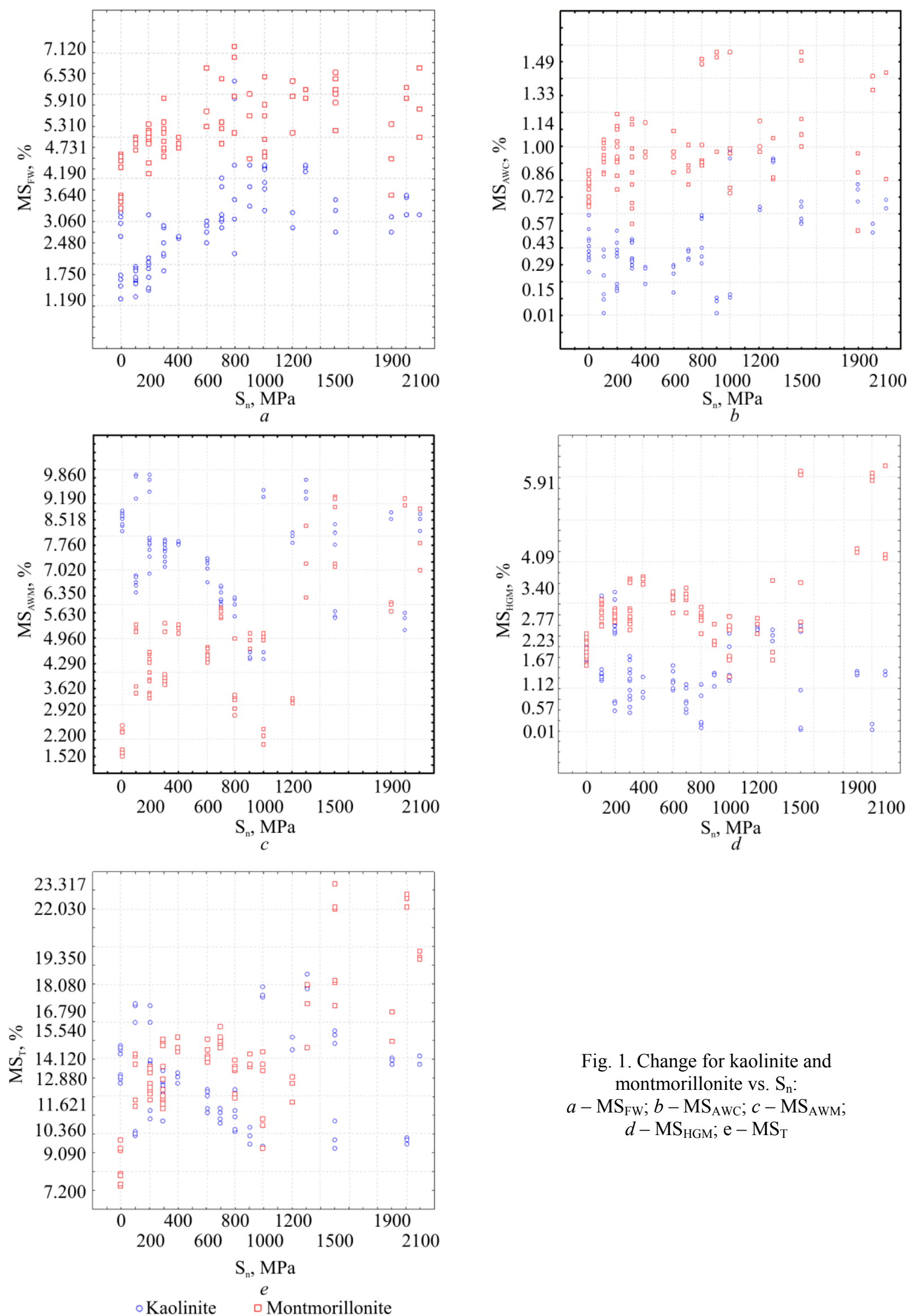

Fig. 1. Change for kaolinite and montmorillonite vs. $\mathrm{S}_{\mathrm{n}}$ :

$a-\mathrm{MS}_{\mathrm{FW}} ; b-\mathrm{MS}_{\mathrm{AWC}} ; c-\mathrm{MS}_{\mathrm{AWM}}$; $d-\mathrm{MS}_{\mathrm{HGM}} ; \mathrm{e}-\mathrm{MS}_{\mathrm{T}}$ 
Table 2

Correlation matrix

\begin{tabular}{|c|c|c|c|c|c|c|c|}
\hline & $\mathrm{S}_{\mathrm{n}}$ & $\mathrm{MS}_{\mathrm{FW}}$ & $\mathrm{MS}_{\mathrm{AWC}}$ & $\mathrm{MS}_{\mathrm{AWM}}$ & $\mathrm{MS}_{\mathrm{HGM}}$ & $\mathrm{MS}_{\mathrm{RCM}}$ & $\mathrm{MS}_{\mathrm{T}}$ \\
\hline \multirow{2}{*}{$S_{n}$} & 1.00 & $\underline{0.53 *}$ & $\underline{0.56^{*}}$ & $-0.21^{*}$ & $-0.23^{*}$ & $-0.39 *$ & -0.01 \\
\hline & $\overline{1.00}$ & $0.54^{*}$ & $0.38^{*}$ & $0.71 *$ & $0.61 *$ & - & $0.75 *$ \\
\hline \multirow{2}{*}{$\mathrm{MS}_{\mathrm{FW}}$} & & $\underline{1.00}$ & $\underline{0.42 *}$ & $-0.38^{*}$ & $-0.39^{*}$ & $-0.39^{*}$ & $\underline{0.02}$ \\
\hline & & 1.00 & $0.37^{*}$ & 0.24 & 0.26 & - & $0.50 *$ \\
\hline \multirow{2}{*}{$\mathrm{MS}_{\mathrm{AWC}}$} & & & $\underline{1.00}$ & $0.43 *$ & $\underline{0.07}$ & -0.02 & $0.55^{*}$ \\
\hline & & & $\overline{1.00}$ & $0.41^{*}$ & $0.36^{*}$ & - & $0.52 *$ \\
\hline \multirow{2}{*}{$\mathrm{MS}_{\mathrm{AWM}}$} & & & & $\underline{1.00}$ & $\underline{0.71^{*}}$ & $0.69^{*}$ & $\underline{0.69 *}$ \\
\hline & & & & 1.00 & $0.92 *$ & - & $0.95 *$ \\
\hline \multirow{2}{*}{$\mathrm{MS}_{\mathrm{HGM}}$} & & & & & $\underline{1.00}$ & $\underline{0.78^{*}}$ & $\underline{0.78 *}$ \\
\hline & & & & & 1.00 & - & $0.93 *$ \\
\hline \multirow{2}{*}{$\mathrm{MS}_{\mathrm{RCM}}$} & & & & & & 1.00 & $0.73^{*}$ \\
\hline & & & & & & 1.00 & - \\
\hline \multirow[t]{2}{*}{$\mathrm{MS}_{\mathrm{T}}$} & & & & & & & $\underline{1.00}$ \\
\hline & & & & & & & 1.00 \\
\hline
\end{tabular}

Changes in values of $\mathrm{MS}_{\mathrm{FW}}$ depending on $\mathrm{S}_{\mathrm{n}}$ for kaolinite and montmorillonite are close, but displaced from each other. The dependence for kaolinite is located slightly lower than for montmorillonite. Note that there are almost linear trends of increase of $\mathrm{MS}_{\mathrm{FW}}$ both for kaolinite and montmrillonite before values $\mathrm{S}_{\mathrm{n}}<1000 \mathrm{MPa}$. Then with increase in $\mathrm{S}_{\mathrm{n}}$ values of $\mathrm{MS}_{\mathrm{FW}}$ are maintained almost the same. This allows concluding that to extract the same mass of film water for kaolinite there is a need of bigger values of $S_{n}$ than for montmorillonite. This is also proved by the mean values of $\mathrm{MS}_{\mathrm{FW}}$ for kaolinite and montmorillonite, given in Table 1. It has to be noted that values of coefficients of $r$ between $\mathrm{MS}_{\mathrm{FW}}$ and $\mathrm{S}_{\mathrm{n}}$ are statistically significant. There is a stronger bond for kaolinite, than for montmorillonite. The dependence looks like

- for kaolinite:

$$
\mathrm{MS}_{\mathrm{FW}}=2.258+0.000837 \mathrm{~S}_{\mathrm{n}}
$$

- for montmorillonite:

$$
\mathrm{MS}_{\mathrm{FW}}=4.675+0.000701 \mathrm{~S}_{\mathrm{n}}
$$

Note that these dependancies describe relationship between $\mathrm{MS}_{\mathrm{FW}}$ and $\mathrm{S}_{\mathrm{n}}$ only for $\mathrm{S}_{\mathrm{n}}<1000 \mathrm{MPa}$, which is well described on Fig. 1, $a$.

Dependence of change in values of $\mathrm{MS}_{\mathrm{AWC}}$ on $\mathrm{S}_{\mathrm{n}}$ is shown in Fig. 1, b. It is seen that the same pattern as above is observed for $\mathrm{MS}_{\mathrm{AWC}}$, but with less loss of water mass. Data on mean values, given in Table 1, indicate that mass loss of water is much lower. Values of coefficients $r$ between $\mathrm{MS}_{\mathrm{AWC}}$ and $\mathrm{S}_{\mathrm{n}}$ are statistically important. There is a tighter bond for kaolinite, than for montmorillonite.

Dependance looks like:

- for kaolinite:

$$
\mathrm{MS}_{\mathrm{AWC}}=0.266+0.000204 \mathrm{~S}_{\mathrm{n}}
$$

- for montmorillonite:

$$
\mathrm{MS}_{\mathrm{AWC}}=0.863+0.000154 \mathrm{~S}_{\mathrm{n}} .
$$

It should be noted that these dependences well describe relationships between $\mathrm{MS}_{\mathrm{AWC}}$ and $\mathrm{S}_{\mathrm{n}}$ also only for values of $S_{n}<1000 \mathrm{MPa}$, as seen in Fig. 1, $b$.

Dependance of change in $\mathrm{MS}_{\mathrm{AWM}}$ on $\mathrm{S}_{\mathrm{n}}$ is presented on Fig. 1, $c$. According to $\mathrm{MS}_{\mathrm{AWM}}$ there are significantly different in direction and value scenarios. There is a decrease in $\mathrm{MS}_{\mathrm{AWM}}$ for kaolinite at values of $S_{n}<1000 \mathrm{MPa}$. There are at first increase in $\mathrm{MS}_{\mathrm{AWM}}$ for montmorillonite at values of $S_{n}<1000 \mathrm{MPa}$ and then decrease. Then there is a chaotic change in $\mathrm{MS}_{\mathrm{AWM}}$ both for kaolinite and montmorillonite. There are fundamental differences for kaolinite and montmorillonite under decrease of $S_{n}$ according to $\mathrm{MS}_{\mathrm{AWM}}$. Value of $r$ coefficient between $\mathrm{MS}_{\mathrm{AWM}}$ and $S_{n}$ for kaolinite is negative and looks like

$$
\mathrm{MS}_{\mathrm{AWM}}=7.775-0.000457 \mathrm{~S}_{\mathrm{n}} \text {. }
$$

There is titgher and positive bond for montmorillonite

$$
\mathrm{MS}_{\mathrm{AM}}=3.129+0.00228 \mathrm{~S}_{\mathrm{n}}
$$

Value of $S_{n}=1000 \mathrm{MPa}$ devide selection into 2 classes that is seen on Fig. 1, $c$. Dependence of change in values of $\mathrm{MS}_{\mathrm{HGM}}$ on $\mathrm{S}_{\mathrm{n}}$ is shown in Fig. 1, $d$.

Values of $\mathrm{MS}_{\mathrm{HGM}}$ for montmorillonite depending on $S_{n}$, in general are higher, than for kaolinite, especially when $\mathrm{S}_{\mathrm{n}}>1000 \mathrm{MPa}$. $\mathrm{MS}_{\mathrm{HGM}}$ changes randomly for kaoplinite with increase of $\mathrm{S}_{\mathrm{n}}$. There is a complex change in $\mathrm{MS}_{\mathrm{HGM}}$ for montmorillonite with increase of $S_{n}$. Here are fundamental different changes for kaolinite and montmorillonite with increase of values of $S_{n}$ as in case for $\mathrm{MS}_{\mathrm{AWM}}$. Values of $r$ coefficients between $\mathrm{MS}_{\mathrm{HGM}}$ and $\mathrm{S}_{\mathrm{n}}$ are negative for kaolinite. There is a 
direct and tighter bond for montmorillonite. A dependance for kaolinite looks like

$$
\mathrm{MS}_{\mathrm{HGM}}=1.673-0.000308 \mathrm{~S}_{\mathrm{n}} \text {. }
$$

Note that this dependence mainly describes data obtained for values of $\mathrm{S}_{\mathrm{n}}<1000 \mathrm{MPa}$, as is seen in Fig. $1, d$. The correlation for montmorillonites is statistically straight, tight and looks like

$$
\mathrm{MS}_{\mathrm{HGM}}=2.665+0.00107 \mathrm{~S}_{\mathrm{n}} .
$$

Note that this dependence, on contrary, describes data better $\mathrm{S}_{\mathrm{n}}>1000 \mathrm{MPa}$ (see Fig. 1, d).

The dependence of change in values of $\mathrm{MS}_{\mathrm{RCM}}$ on $\mathrm{S}_{\mathrm{n}}$ is shown in Fig. 2.

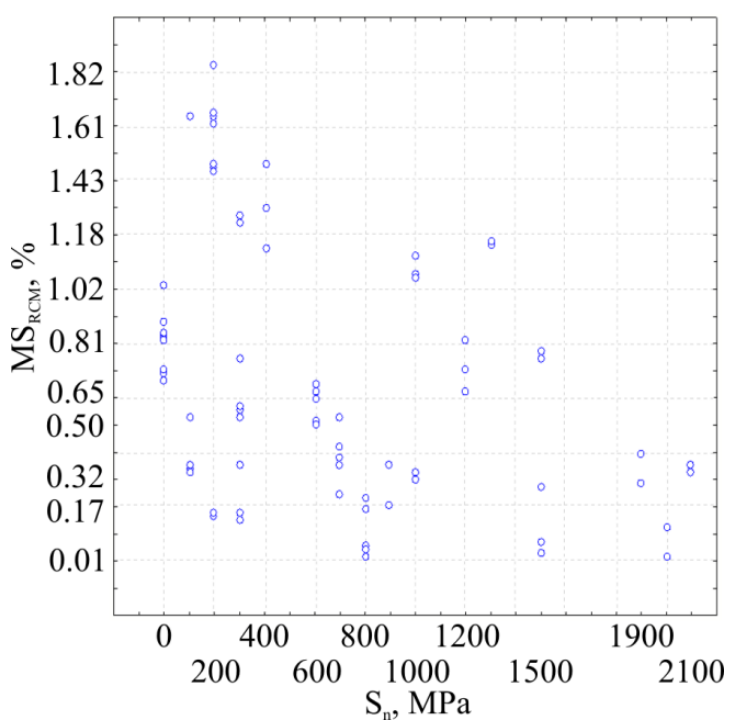

Fig. 2. Dependance of $\mathrm{MS}_{\mathrm{RCM}}$ change on $\mathrm{S}_{\mathrm{n}}$ for kaolinite

An analysis of change in $\mathrm{MS}_{\mathrm{RCM}}$ values versus $\mathrm{S}_{\mathrm{n}}$ for kaolinites shows that in case dependence is consider as a whole, there would be a trend of decrease of $\mathrm{MS}_{\mathrm{RCM}}$ values with increase in $\mathrm{S}_{\mathrm{n}}$. Such correlation would be statistically significant. However, if this dependence is considered in more detail, there would be two sub-dependencies observed. The first sub-dependence appear to be at $\mathrm{S}_{\mathrm{n}}<1000 \mathrm{MPa}$, the second at $\mathrm{S}_{\mathrm{n}}>1000 \mathrm{MPa}$.

Changes in $\mathrm{MS}_{\mathrm{T}}$ values as a function of $\mathrm{S}_{\mathrm{n}}$, presented in Fig. 1, $d$, show that with increase of $S_{n}$, an $\mathrm{MS}_{\mathrm{T}}$ value varies randomly for kaolinites which is proved by a low value of $r$ coefficient $r=-0.01$.

However, there is a regular decrease of $\mathrm{MS}_{\mathrm{T}}$ values at $\mathrm{S}_{\mathrm{n}}<1000 \mathrm{MPa}$ at in-depth analysis.
Then there is a sharp increase in $\mathrm{MS}_{\mathrm{T}}$ values with following decrease again. There is quite complex change in $\mathrm{MS}_{\mathrm{T}}$ values for montmorillonite with increase in $\mathrm{S}_{\mathrm{n}}$. Neverthelles, in general there is a tight positive trend, that is described as follows:

$$
\mathrm{MS}_{\mathrm{T}}=10.934+0.00421 \mathrm{~S}_{\mathrm{n}}
$$

Consequantly, it was found that pressure affect mass loss in variety of bound water types in clays differently in direction. It was found that there is sudden change in loss of bound water mass at pressures of about $1000 \mathrm{MPa}$. Therefore, it can be assumed that at pressures up to $1000 \mathrm{MPa}$ bound water is formed according to one scenario and to another scenarion at $\mathrm{S}_{\mathrm{n}}>1000 \mathrm{MPa}$.

Therefore, legitimacy of existence of proposed hypothesis was studied in the second stage. The hypothesis says that distinguished ranges of values of $S_{n}$ are statistically different by a set of indicators.

To do that a stepwise linear discriminant analysis (SLDA) was used. Possibilities of using such analysis to solve similar issues are given in [13-15]. For development of models it was assumed that the first sample (class 1) consists of values of $S_{n}<1000 \mathrm{MPa}$ and the second sample (class 2) consists of values of $S_{n}>1000 \mathrm{MPa}$.

As a result of implimentation of this method, following linear discriminant function was obtained for kaolinite:

$$
\begin{aligned}
& Z_{\mathrm{k}}=-11.6559 \mathrm{MS}_{\mathrm{AWC}}+1.1717 \mathrm{MS}_{\mathrm{AWM}}- \\
& -0.9982 \mathrm{MS}_{\mathrm{HGM}}+0.5777 \mathrm{MS}_{\mathrm{FW}}-4.186
\end{aligned}
$$

where $R=0.851, \chi^{2}=118.23, p=0.000$.

A mean value for the first class (sample) is $Z_{\mathrm{k}_{1}}=0.923$ and for the second $Z_{\mathrm{k}_{2}}=-2.77$.

The probabilities of experimental data, belonging to the second class $P\left(Z_{\mathrm{K}_{2}}\right)$, were calculated using the function given above [16-17]. For the $2^{\text {nd }}$ class mean value and variance are $P\left(Z_{\mathrm{k}_{2}}\right)=0.982$ and $\sigma_{2}^{2}= \pm 0.059, P\left(Z_{\mathrm{K}_{1}}\right)=0.016$ and $\sigma_{1}{ }^{2}= \pm 0.022$ for the $1^{\text {st }}$ class. It has to be noted that there was $100 \%$ of right recognition by this function.

As a result of this method implementation following linear discriminant function was obtained for montmorillonite: 


$$
\begin{gathered}
Z_{\mathrm{m}}=0.11299 \mathrm{MS}_{\mathrm{AWC}}-1.07678 \mathrm{MS}_{\mathrm{AWM}}+ \\
+0.12472 \mathrm{MS}_{\mathrm{HGM}}+2.863
\end{gathered}
$$

at $R=0.860, \chi^{2}=125.018, p=0.000$.

A mean value for the first class (sample) is $Z_{\mathrm{k}_{1}}=0.966$, for the second class $-Z_{\mathrm{k}_{2}}=-2.90$.

For this function, values of probability of experimental data, belonging to the second class, were calculated $-P\left(Z_{\mathrm{k}_{2}}\right)$. Mean value and variance for the $2^{\text {nd }}$ class are $P\left(Z_{\mathrm{k}_{2}}\right)=0.939$ and $\sigma_{2}^{2}= \pm 0.117, P\left(Z_{\mathrm{k}_{1}}\right)=0.029$ and $\sigma_{1}^{2}= \pm 0.073$ for the $1^{\text {st }}$ class. It has to be noted that there was $100 \%$ of right recognition for both classes by this function.

Mean values of indicators for kaolinite and montmorillonite, taking into account division of samples into classes 1 and 2, obtained using LDF, (Table 3) are given below.

Table 3

Comparison of mean values of kaolinite and

\begin{tabular}{|c|c|c|c|c|}
\hline \multirow{2}{*}{ Parameter } & \multicolumn{2}{|c|}{$\begin{array}{l}\text { Mean values and variance } \\
\text { of values }\end{array}$} & \multicolumn{2}{|c|}{ Student's coefficien } \\
\hline & class 1 & class 2 & $\begin{array}{c}t_{p}- \\
\text { calculated }\end{array}$ & $\begin{array}{c}t_{t}- \\
\text { critical }\end{array}$ \\
\hline \multicolumn{5}{|c|}{ Kaolinite } \\
\hline $\mathrm{S}_{\mathrm{n}}, \mathrm{MPa}$ & $358.3 \pm 324.6$ & $1725.0 \pm 349.4$ & \multicolumn{2}{|c|}{$12.3988>1.98$} \\
\hline $\mathrm{MS}_{\mathrm{FW}}, \%$ & $2.3 \pm 0.9$ & $3.5 \pm 0.5$ & \multicolumn{2}{|c|}{$3.1375>1.98$} \\
\hline $\mathrm{MS}_{\mathrm{AWC}}, \%$ & $0.30 \pm 0.11$ & $0.69 \pm 0.15$ & \multicolumn{2}{|c|}{$9,0985>1.98$} \\
\hline $\mathrm{MS}_{\mathrm{AWM}}, \%$ & $7.3 \pm 1.3$ & $7.8 \pm 1.5$ & \multicolumn{2}{|c|}{$1.2126<1.98$} \\
\hline $\mathrm{MS}_{\mathrm{HGM}}, \%$ & $1.45 \pm 0.75$ & $1.54 \pm 0.98$ & \multicolumn{2}{|c|}{$0.3211<1.98$} \\
\hline $\mathrm{MS}_{\mathrm{RCM}}, \%$ & $0.71 \pm 0.47$ & $0.57 \pm 0.44$ & \multicolumn{2}{|c|}{$0.8859<1.98$} \\
\hline $\mathrm{MS}_{\mathrm{T}}, \%$ & $12.4 \pm 1.9$ & $14.2 \pm 3.1$ & \multicolumn{2}{|c|}{$2.3477>1.98$} \\
\hline \multicolumn{5}{|c|}{ Montmorillonite } \\
\hline $\mathrm{S}_{\mathrm{n}}, \mathrm{MPa}$ & $358.3 \pm 324.6$ & $1725.0 \pm 349.4$ & \multicolumn{2}{|c|}{$12.3988>1.98$} \\
\hline $\mathrm{MS}_{\mathrm{FW}}, \%$ & $4.8 \pm 0.6$ & $5.9 \pm 0.4$ & \multicolumn{2}{|c|}{$6.3182>1.98$} \\
\hline $\mathrm{MS}_{\mathrm{AWC}}, \%$ & $0.90 \pm 0.21$ & $1.07 \pm 0.25$ & \multicolumn{2}{|c|}{$2.3980>1.98$} \\
\hline $\mathrm{MS}_{\mathrm{AWM}}, \%$ & $4.1 \pm 1.2$ & $7.9 \pm 0.9$ & \multicolumn{2}{|c|}{$9.8450>1.98$} \\
\hline $\mathrm{MS}_{\mathrm{HGM}}, \%$ & $2.71 \pm 0.48$ & $4.01 \pm 1.70$ & \multicolumn{2}{|c|}{$4.1605>1.98$} \\
\hline $\mathrm{MS}_{\mathrm{RCM}}, \%$ & - & - & \multicolumn{2}{|c|}{-} \\
\hline $\mathrm{MS}_{\mathrm{T}}, \%$ & $12.5 \pm 2.2$ & $19.0 \pm 2.5$ & \multicolumn{2}{|c|}{$8.5910>1.98$} \\
\hline
\end{tabular}
montmorillonite

There is a significant difference in loss of water mass in $1^{\text {st }}$ and $2^{\text {nd }}$ classes for kaolinite and montmorillonite under different loads. Quantitative evaluation of these differences was carried out using Student's $t$ criterion [18]. Calculated values of $t$ are given in Table 3, while the critical $t_{t}=1.98$ was calculated for $n_{1}=n_{2}=96$ and a significance level $\alpha=0.05$.

There are statistical differences in $\mathrm{MS}_{\mathrm{FW}}, \mathrm{MS}_{\mathrm{AWC}}$ and $\mathrm{MS}_{\mathrm{T}}$ for caolinite, that is proved by the values of $t_{p}>t_{t}$. Herewith, loss of bound water mass for the second class is higher than for the first.

There are statistical differences in all of indicators $\left(t_{p}>t_{t}\right)$ for montmorillonite. Herewith losses for the second class are much higher than for the first. It should be noted that for kaolinite losses in $\mathrm{MS}_{\mathrm{AWM}}$ for two samples (classes) statistically are not different. A maximum statistical difference is observed for montmorillonite. The values of $r$ coefficients between studied parameters for kaolinite and montmorillonite with considered distinguished samples (classes) are given in Table 4.

Table 4

\begin{tabular}{|c|c|c|c|c|c|c|c|}
\hline & $\mathrm{S}_{\mathrm{n}}$ & $\mathrm{MS}_{\mathrm{FW}}$ & $\mathrm{MS}_{\mathrm{AWC}}$ & $\mathrm{MS}_{\mathrm{AWM}}$ & $\mathrm{MS}_{\mathrm{HGM}}$ & $\mathrm{MS}_{\mathrm{RCM}}$ & $\mathrm{MS}_{\mathrm{T}}$ \\
\hline \multicolumn{8}{|c|}{ Kaolinite } \\
\hline \multirow{2}{*}{$\mathrm{S}_{\mathrm{n}}$} & 1.00 & $\underline{0.68^{*}}$ & -0.18 & $-0.85^{*}$ & $-0.50^{*}$ & $-0.44 *$ & $-0.56^{*}$ \\
\hline & $\overline{1.00}$ & $-0.68 *$ & $-0.74 *$ & $-0.58^{*}$ & $-0.77^{*}$ & $-0.93 *$ & $-0.78^{*}$ \\
\hline \multirow{2}{*}{$\mathrm{MS}_{\mathrm{FW}}$} & & 1.00 & 0.20 & $-0.61 *$ & $-0.55^{*}$ & $-0.43 *$ & -0.24 \\
\hline & & 1.00 & $0.76^{*}$ & 0.38 & 0.27 & $0.68^{*}$ & $\overline{0.54}$ \\
\hline \multirow{2}{*}{$\mathrm{MS}_{\mathrm{AWC}}$} & & & $\underline{1.00}$ & $\underline{0.39 *}$ & -0.16 & -0.03 & $\underline{0.37}$ \\
\hline & & & 1.00 & $0.87^{*}$ & $0.69 *$ & $0.90^{*}$ & $0.92 *$ \\
\hline \multirow{2}{*}{$\mathrm{MS}_{\mathrm{AWM}}$} & & & & 1.00 & $0.68^{*}$ & $0.69 *$ & $0.85^{*}$ \\
\hline & & & & 1.00 & $0.85^{*}$ & $0.83^{*}$ & $0.96^{*}$ \\
\hline \multirow{2}{*}{$\mathrm{MS}_{\mathrm{HGM}}$} & & & & & 1.00 & $\underline{0.78^{*}}$ & $\underline{0.77^{*}}$ \\
\hline & & & & & $\overline{1.00}$ & $0.88^{*}$ & $0.92 *$ \\
\hline \multirow{2}{*}{$\mathrm{MS}_{\mathrm{RCM}}$} & & & & & & $\underline{1.00}$ & $\underline{0.82^{*}}$ \\
\hline & & & & & & $\overline{1.00}$ & $0.95^{*}$ \\
\hline $\mathrm{MS}_{\mathrm{T}}$ & & & & & & & $\underline{1.00}$ \\
\hline \multicolumn{7}{|c|}{ Montmorillonite } & 1.00 \\
\hline \multirow{2}{*}{$\mathrm{S}_{\mathrm{n}}$} & 1.00 & $0.55^{*}$ & 0.48 & $0.53^{*}$ & $0.38^{*}$ & & $0.58 *$ \\
\hline & 1.00 & -0.16 & -0.47 & $0.48^{*}$ & $0.83^{*}$ & & $0.79^{*}$ \\
\hline \multirow{2}{*}{$\mathrm{MS}_{\mathrm{FW}}$} & & 1.00 & $\underline{0.02}$ & $0.69^{*}$ & $0.80^{*}$ & & $\underline{0.83}$ \\
\hline & & 1.00 & -0.29 & -0.20 & 0.01 & & 0.06 \\
\hline \multirow{2}{*}{$\mathrm{MS}_{\mathrm{AWC}}$} & & & $\underline{1.00}$ & $\underline{0.41^{*}}$ & 0.19 & & $0.36^{*}$ \\
\hline & & & 1.00 & $0.75^{*}$ & 0.54 & & $0.72 *$ \\
\hline \multirow{2}{*}{$\mathrm{MS}_{\mathrm{AWM}}$} & & & & $\underline{1.00}$ & $\underline{0.83^{*}}$ & & $\underline{0.97 *}$ \\
\hline & & & & $\overline{1.00}$ & $\overline{0.42}$ & & $\overline{0.73 *}$ \\
\hline \multirow{2}{*}{$\mathrm{MS}_{\mathrm{HGM}}$} & & & & & 1.00 & & $\underline{0.91 *}$ \\
\hline & & & & & 1.00 & & $0.91 *$ \\
\hline \multicolumn{8}{|l|}{$\mathrm{MS}_{\mathrm{RCM}}$} \\
\hline $\mathrm{MS}_{\mathrm{T}}$ & & & & & & & $\frac{1.00}{1.00}$ \\
\hline
\end{tabular}

Correlation matrix

Remarks: *- significant correlation bonds, in a nominator - class 1 , in denominator - class 2 .

Comparison of $r$ values shows that there are significant differences both during division of kaolinite and montmorillonite into samples and inside of samples. For instance, correlation between $\mathrm{S}_{\mathrm{n}}$ and $\mathrm{MS}_{\mathrm{AWM}}$ is statistically significant and negative for the $1^{\text {st }}$ and $2^{\text {nd }}$ classes of kaolinites $\left(r_{p_{1}}=-0.85>r_{t}=0.21\right.$ and $\left.r_{p_{2}}=-0.58>r_{t}=0.21\right)$, statistically significant and positive for 
montmorillonites $\left(r_{p_{1}}=0.53>r_{t}=0.21\right.$ and $\left.r_{p_{2}}=0.48>r_{t}==0.21\right)$. The same differences are observed for other parameters (see Table 4).

Thus, a pressure threshold $\mathrm{S}_{\mathrm{n}}=1000 \mathrm{MPa}$ is established. This pressure divides the population into two classes. Class 1 includes data obtained at pressures of $S_{n}<1000 \mathrm{MPa}$, and class $2-$ at pressures of $S_{n}>1000 \mathrm{MPa}$.

Estimation of loss of various kinds of bound water in clays showed that they differ quite strongly between classes 1 and 2 in montmorillonite and kaolinite clays. Hence it can be assumed that their formation proceeds according to different scenarios.

Therefore, in the third stage, an effect of bound water of different kinds on total loss of water mass in clays was studied. To solve this problem, stepwise regression analysis was used [19-21]. The correlation coefficient $(r)$ was used as the criterion that helps to evaluate influence of studied parameters on $\mathrm{MS}_{\mathrm{T}}$ values.

The possibility to apply this indicator is as follows: the higher $r$ value, the more significant effect of this type of water on the total mass loss of $\mathrm{MS}_{\mathrm{T}}$ [22-23]. In our case $\mathrm{MS}_{\mathrm{T}}$ plays a role of dependent feature and $\mathrm{MS}_{\mathrm{FW}}, \mathrm{MS}_{\mathrm{AWC}}, \mathrm{MS}_{\mathrm{AWM}}$, $\mathrm{MS}_{\mathrm{HGM}}, \mathrm{MS}_{\mathrm{RCM}}-$ independent. Following scenarios are considered:

- first (for kaolinite) - total selection, formed at pressures $\mathrm{S}_{\mathrm{n}}=0-2000 \mathrm{MPa}$;

- second (for kaolinite) - selection 1, formed at pressures $\mathrm{S}_{\mathrm{n}}<1000 \mathrm{MPa}$;
- third (for kaolinite) - selection 2, formed at pressures $\mathrm{S}_{\mathrm{n}}>1000 \mathrm{MPa}$;

- fourth (for montmorillonite) - total selection, formed at pressures $S_{n}=0-2000 \mathrm{MPa}$;

- fifth (for montmorillonite) - selection 1, formed at pressures $\mathrm{S}_{\mathrm{n}}<1000 \mathrm{MPa}$;

- sixth (for montmorillonite) - selection 2, formed at pressures $S_{n}>1000 \mathrm{MPa}$.

Built models are given in Table 5.

An analysis of data given in Table 5 shows that the formation of multidimensional models for calculation of $\mathrm{MS}_{\mathrm{T}}$ values occurs in a different sequence. For joint sampling in kaolinite clay (scenarion 1), the process of model formation begins with adsorbed mineral water $(r=0.867)$ and continue with parameters that characterise film colloidal water $(r=0.945)$, hydroxyl groups of a mineral $(r=0.993)$ and recrystallized mineralization $(r=0.998)$. A similar pattern was identified in scenario 2 . Major part in variation of $\mathrm{MS}_{\mathrm{T}}$ in $3^{\text {rd }}$ sce nario (at $\mathrm{S}_{\mathrm{n}}>1000 \mathrm{MPa}$ ) is brought by the index of adsorbed mineral water $(r=0.846)$. At the second step, unlike option 1, an indicator that characterize mass loss during recrystallization of the mineral $(r=0.991)$. At the third step $-\mathrm{MS}_{\mathrm{HGM}}(r=0.993)$ and the fourth $-\mathrm{MS}_{\mathrm{FW}}(r=0.999)$.

Thus, adsorbed water of mineral is major reason of total loss of mass of bound water [24]. Depending on pressure, second place belongs to film water (at $S_{n}<1000 \mathrm{MPa}$ ) and recrystallization of minerals (at $S_{n}>1000 \mathrm{MPa}$ ).

Table 5

Multidimensional models for calculation of $\mathrm{MS}_{\mathrm{T}}$

\begin{tabular}{|c|c|c|c|c|c|c|c|}
\hline & \multirow{2}{*}{ Scenario } & \multirow{2}{*}{ Free term } & \multicolumn{5}{|c|}{ Types of bound water } \\
\hline & & & $\mathrm{MS}_{\mathrm{FW}}$ & $\mathrm{MS}_{\mathrm{AWC}}$ & $\mathrm{MS}_{\mathrm{AVM}}$ & $\mathrm{MS}_{\mathrm{HGM}}$ & $\mathrm{MS}_{\mathrm{RCM}}$ \\
\hline \multirow[t]{2}{*}{ First } & coefficients & -1.05413 & $\frac{1.13632 *}{0.945}$ & & $\frac{1.16559}{0.867}$ & $\frac{0.98018}{0.993}$ & $\frac{0.80678}{0.998}$ \\
\hline & order to build the model & & 2 & & 1 & 3 & 4 \\
\hline \multirow{2}{*}{ Second } & coefficients & -0.65403 & $\frac{1.07218}{0.916}$ & & $\frac{1.12806}{0.847}$ & $\frac{0.92678}{0.990}$ & $\frac{0.91262}{0.999}$ \\
\hline & order to build the model & & 2 & & 1 & 3 & 4 \\
\hline \multirow[t]{2}{*}{ Third } & coefficients & -0.093371 & $\frac{1.05074}{0.999}$ & & $\frac{1.08152}{0.846}$ & $\frac{0.90393}{0.993}$ & $\frac{1.23638}{0.991}$ \\
\hline & order to build the model & & 4 & & 1 & 3 & 2 \\
\hline \multirow[t]{2}{*}{ Fourth } & coefficients & 0.008447 & $\frac{1.02352}{0.922}$ & $\frac{0.62194}{0.998}$ & $\frac{0.34881}{0.867}$ & $\frac{2.01826}{0.864}$ & \\
\hline & order to build the model & & 2 & 4 & 3 & 1 & \\
\hline \multirow[t]{2}{*}{ Fifth } & coefficients & 0.581344 & $\frac{1.09253}{0.989}$ & & $\frac{1.09294}{0.923}$ & $\frac{0.82505}{0.995}$ & \\
\hline & order to build the model & & 2 & & 1 & 3 & \\
\hline \multirow[t]{2}{*}{ Sixth } & coefficients & 4.214447 & $\frac{0.82877}{0.872}$ & & & $\frac{2.11214}{0.862}$ & \\
\hline & order to build the model & & 2 & & & 1 & \\
\hline
\end{tabular}

R e m a r k s . *Nominator - coefficients at indexes in equations, denominator - value of correlation coefficient $R$. 
Pressure influence formation of $\mathrm{MS}_{\mathrm{T}}$ much in montmorrilonite than in kaolinite clay.

Adsorbed mineral water has the most significant effect on formation of $\mathrm{MS}_{\mathrm{T}}$ in scenarion $5(r=0.923)$ in scenario 6 water of hydroxyl groups $(r=0.862)$. Second place by the influence on formarion of $\mathrm{MS}_{\mathrm{T}}$ according to scenarios 5 and 6 is taken by film water.

Thus, taking into account class division and depending on pressure studied parameters influence formation of $\mathrm{MS}_{\mathrm{T}}$ in kaolinite and montmorillonite differently. That fact is proved by different mathematical models [25-28]. Neverthelles, in all the cases (except scenario 6) the most significant factor that determines formation of $\mathrm{MS}_{\mathrm{T}}$ is adsorbed mineral water. For $6^{\text {th }}$ scenario that is water of hydroxyl groups.

\section{Conclusion}

1. It is determined that at the pressures less that $1000 \mathrm{MPa}$ there is different in directions change in total mass of loss water. Total mass of loss water is decreased with increase in pressure in kaolinite clay and is increased in montmorillonite clay [29-30]. Under the pressures of $1000 \mathrm{MPa}$ such laws do not work. The mathematical models that help to understand a mechanism of mass loss of water in clays depending on pressure are developed.

2. It is determined and proved mathematically that threshold equals to $1000 \mathrm{MPa}$, at which mass loss of water in clays between classes 1 and 2 are different. Taking into account class division and depending on pressure studied parameters influence total mass loss of water differently in caolinite and montmorillonite. That is proved by different mathematical models. Neverthelles, in all the cases except for montmorillonite affected by $1000 \mathrm{MPa}$, the most significant factor that determines change of total mass loss of water is adsorbed water of minerals.

\section{References}

1. Seredin V.V., Iadzinskaia M.R., Krasil'nikov P.A. Prognoz prochnostnykh svoistv peskov, zagriaznennykh uglevodorodami [Forecast of mechanical properties of sands contaminated with hydrocarbons]. Inzhenernaia geologiia, 2014, no.6, pp.50-55.

2. Osipov V.I., Sokolov V.N. Gliny i ikh svoistva. Sostav, stroenie i formirovanie svoistv [Clays and their properties. Composition, structure and formation of properties]. Moscow, GEOS, 2013, 576 p.

3. Zlochevskaia R.I., Korolev V.A., Krivosheeva Z.A., Sergeev E.M. O prirode izmeneniia svoistv sviazannoi vody $\mathrm{V}$ glinakh pod deistviem po-vyshaiushchikh temperatur i davlenii [On the nature of change in properties of bound water in clays under action of increasing temperatures and pressures]. Vestnik Moskovskogo universiteta. Seriia Geologiia, 1977, no.3, pp.80-96.

4. Krivosheeva Z.A., Zlochevskaia R.I., Korolev V.A., Sergeev E.M. O prirode izmeneniia sostava i svoistv glinistykh porod $\mathrm{v}$ protsesse litogeneza [On the nature of changes in composition and properties of clay rocks in lithogenesis]. Vestnik Moskovskogo universiteta. Seriia Geologiia, 1977, no.4, pp.60-73.

5. Kuprina G.A. Osobennosti termicheskoi degidratatsii montmoril-lonitovoi i kaolinitovoi glin i sostoianiia $\mathrm{v}$ nikh sviazannoi vody [Features of thermal dehydration of montmorillonite and kaolinite clays and condition of bound water inside]. Voprosy inzhenernoi geologii $i$ gruntovedeniia, 1973, iss.3, pp.56-67.

6. Shurygina E.A. Termicheskoe issledovanie adsorbirovannoi vody $\mathrm{v}$ glinistykh mineralakh i pochvakh [Thermal study of adsorbed water in clay minerals and soils]. Materialy soveshchaniia po issledovaniiu i ispol'zovaniiu glin. L'vov, 1958, pp.760-768.
7. Xia Bian, Zhen-Shun Hong, Jian-Wen Ding. Evaluating the effect of soil structure on the ground response during shield tunnelling in Shanghai soft clay. Tunnelling and Underground Space Technology, 2016, vol. 58, pp.120-132. DOI: 10.1016/j.tust.2016.05.003

8. Moorak Son. Response analysis of nearby structures to tunneling-induced ground movements in clay soils. Tunnelling and Underground Space Technology, 2016, vol.56, pp.90-104. DOI: 10.1016/j.tust.2016.01.032

9. Mooney M.A., Grasmick J., Kenneally B., Fang Y. The role of slurry TBM parameters on ground deformation: Field results and computational modelling. Tunnelling and Underground Space Technology, 2016, vol. 57, pp.257-264. DOI: 10.1016/j.tust.2016.01.007

10. Jie Zhou, Yiqun Tang. Centrifuge experimental study of thaw settlement characteristics of mucky clay after artificial ground freezing. Engineering Geology, 2015, vol.190, pp.98-108. DOI: 10.1016/j.enggeo.2015.03.002

11. Chuan Gu, Jun Wang, Yuanqiang Cai, Lei Sun, Peng Wang, QuanYang Dong. Deformation characteristics of over consolidated clay sheared under constant and variable confining pressure. Soils and Foundations, 2016, vol.56, iss.3, pp.427-439. DOI: 10.1016/j.sandf.2016.04.009

12. Raitburd Ts.M., Kul'chitskii L.I., Slonimskaia M.V., Sa-lyn' A.L. O prirode energeticheskoi neodnorodnosti adsorbirovannoi vody glin $[\mathrm{On}$ the nature of energy inhomogeneity of adsorbed clay water]. Kriogennye protsessy $v$ gornykh porodakh. Moscow, 1965, pp.55-64.

13. Galkin V.I., Rastegaev A.V., Kozlova I.A., Vantseva I.V., Krivo-shchekov S.N., Voevodkin V.L. Prognoznaia otsenka neftegazonosnosti struktur na territorii Solikamskoi depressii [Probable 
estimation of oil content of structures in territory of Solikamsk depression]. Neftepromyslovoe delo, 2010, no.7, pp.4-7.

14. Betekhtin A.G. Kurs mineralogii [Course of Mineralogy]. Moscow, KDU, 2010, 736 p.

15. Enikolopian N.S., Mkhitarian A.A., Karagezian A.S. Sverkhbystrye reaktsii razlozheniia $\mathrm{v}$ tverdykh telakh pod davleniem [Ultrafast decomposition feedback in solids under pressure]. Doklady Akademii nauk SSSR, 1986, vol.288. no.3, pp.657-660.

16. Krivoshchekov S.N., Galkin V.I., Volkova A.S. Razrabotka veroiatnostno-statisticheskoi metodiki prognoza neftegazonosnosti struktur [Development of the probabilistic and statistical method of oil and gas content of formations]. Neftepromyslovoe delo, 2010, no.7, pp.28-31.

17. Rentgenograficheskii kolichestvennyi fazovyi analiz (RKFA) glinistykh mineralov (kaolinita, gidrosliudy, montmorilonita). Metodicheskie rekomendatsii № 139 [Radiographic quantitative phase analysis (RQPA) of clay minerals (kaolinite, hydro mica, montmorillonite). Methodical recommendations No. 139]. Moscow, Nauchnyi sovet po metodam mineralogicheskikh issledovanii Vserossiiskogo nauchno-issledovatel'skogo instituta mineral'nogo syr'ia im. N.M. Fedorovskogo, 1999.

18. Seredin V.V., Khrulev A.S. Izmeneniia temperatury obraztsov gornykh porod i geomaterialov pri ikh razrushenii [Changes in temperature of rock samples and geomaterials during their destruction]. Fizikotekhnicheskie problemy razrabotki poleznykh iskopaemykh, 2016, no.4, pp.63-69.

19. Trofimov V.T., Korolev V.A., Voznesenskii V.A., Golodkovskaia G.A., Vasil'chuk Iu.K., Ziangirov R.S. Gruntovedenie [Ground science]. Moscow, Izdatel'stvo Moskovskogo gosudarstvennogo universiteta, 2005, 1024 p.

20. Chikov B.M., Kargapolov S.A., Ushakov G.D. Eksperimental'noe stress-preobrazovanie piroksenita [Experimental stress transformation of pyroxenite]. Geologiia $i$ geofizika, 1989, no.6, pp.75-79.

21. Shlykov V.G. Ispol'zovanie strukturnykh kharakteristik glinistykh mineralov dlia otsenki fizikokhimicheskikh svoistv dispersnykh gruntov [Use of structural characteristics of clay minerals to assess physical and chemical properties of dispersed soils]. Geoekologiia, 2000, no.1, pp.43-52.

22. Tang L., Sparks D.L. Cation-exchange kinetics on montmorillonite using pressure-jump relaxation. Soil Science Society of America Journal, 1993, vol.57, no.1, pp.42-46. DOI: $10.2136 /$ sssaj1993.03615995005700010009x

23. Agha M.A., El Ghar M.S.A., Ferrell R.E., Hart G.F., Abdel-Motelib A. Mineralogy of egyptian bentonitic clays ii: geologic origin. Clays and clay minerals, 2014, vol.61, no.6, pp.551-565.

24. Adriaens R., Vandenberghe N., Elsen J. Natural clay-sized glauconite in the neogene deposits of the campine basin (belgium). Clays and clay minerals, 2014, vol.62, no.1, pp.35-52.

25. Friedlander L.R., Glotch T.D., Phillips B.L., Vaughn J.S., Michalski J.R. Examining structural and related spectral change in marsrelevant phyllosilicates after experimental impacts between 10-40 gpa. Clays and clay minerals, 2016, vol.64, no.3, pp.35-52.

26. Ercan H.Ü., Işik Ece Ö., Schroeder P.A., Karacik Z. Differentiating styles of alteration within kaolin-alunite hydrothermal deposits of çanakkale, nw turkey. Clays and clay minerals, 2016, vol.64, no.3, pp.245-274.

27. Seredin V.V., Yadzinskaya M.R. Issledovaniya mekhanizma agregatsii chastits $\mathrm{V}$ glinistykh gruntakh pri zagryaznenii ikh uglevodorodami [Study of the mechanism of aggregation of particles in clay soils with their contamination by hydrocarbons]. Fundamentalnye issledovaniya, 2014, no.8-6, pp.1408-1412.

28. Seredin V.V., Kachenov V.I., Siteva O.S., Paglazova D.N. Izuchenie zakonomernostej koagulyatsii glinistykh chastits [Study of the law of clay particles coagulation]. Fundamentalnye issledovaniya, 2013, no.10-14, pp.3189-3193.

29. Osovetskij B.M. Drobnaya granulometriya allyuviya [Fractional granulometry of alluvium]. Perm, Izdatel'stvo Permskogo universiteta, 1993, 343 p.

30. Korolev V.A. Modelirovanie granulometricheskogo sostava lunnykh gruntov [Modeling of granulometric composition of lunar soils]. Inzhenernaya geologiya, 2016, no.5, pp.40-50.

\section{Библиографический список}

1. Середин В.В., Ядзинская М.Р., Красильников П.А. Прогноз прочностных свойств песков, загрязненных углеводородами // Инженерная геология. - 2014. - № 6. - С. 50-55.

2. Осипов В.И., Соколов В.Н. Глины и их свойства. Состав, строение и формирование свойств. - М.: ГЕОС, 2013. $-576 \mathrm{c}$.

3. О природе изменения свойств связанной воды в глинах под действием повышающих температур и давлений / Р.И. Злочевская, В.А. Королев, 3.А. Кривошеева, Е.М. Сергеев // Вестник Московского университета. Сер. Геология. - 1977. - № 3. - С. 80-96.

4. О природе изменения состава и свойств глинистых пород в процессе литогенеза / З.А. Кривошеева, Р.И. Злочевская, В.А. Королев, Е.М. Сергеев // Вестник Московского университета. Сер. Геология. - 1977. - № 4. - С. 60-73.
5. Куприна Г.А. Особенности термической дегидратации монтмориллонитовой и каолинитовой глин и состояния в них связанной воды // Вопросы инженерной геологии и грунтоведения. - 1973. - Вып. 3. - С. 56-67.

6. Шурыгина Е.А. Термическое исследование адсорбированной воды в глинистых минералах и почвах // Материалы совещания по исследованию и использованию глин. - Львов, 1958. - С. 760-768.

7. Xia Bian, Zhen-Shun Hong, Jian-Wen Ding. Evaluating the effect of soil structure on the ground response during shield tunnelling in Shanghai soft clay // Tunnelling and Underground Space Technology. - 2016. Vol. 58. - P. 120-132. DOI: 10.1016/j.tust.2016.05.003

8. Moorak Son. Response analysis of nearby structures to tunneling-induced ground movements in clay soils // 
Tunnelling and Underground Space Technology. - 2016. Vol. 56. - P. 90-104. DOI: 10.1016/j.tust.2016.01.032

9. The role of slurry TBM parameters on ground deformation: Field results and computational modelling / M.A. Mooney, J. Grasmick, B. Kenneally, Y. Fang. // Tunnelling and Underground Space Technology. - 2016. Vol. 57. - P. 257-264. DOI: 10.1016/j.tust.2016.01.007.

10. Jie Zhou, Yiqun Tang. Centrifuge experimental study of thaw settlement characteristics of mucky clay after artificial ground freezing // Engineering Geology. - 2015. Vol. 190. - P. 98-108. DOI: 10.1016/j.enggeo.2015.03.002

11. Deformation characteristics of over consolidated clay sheared under constant and variable confining pressure / Chuan Gu, Jun Wang, Yuanqiang Cai, Lei Sun, Peng Wang, QuanYang Dong // Soils and Foundations. - 2016. - Vol. 56, iss. 3. - P. 427-439. DOI: 10.1016/j.sandf.2016.04.009

12. О природе энергетической неоднородности адсорбированной воды глин / Ц.М. Райтбурд, Л.И. Кульчитский, М.В. Слонимская, А.Л. Салынь // Криогенные процессы в горных породах. - М., 1965. - С. 55-64.

13. Прогнозная оценка нефтегазоносности структур на территории Соликамской депрессии / В.И. Галкин, А.В. Растегаев, И.А. Козлова, И.В. Ванцева, С.Н. Кривощеков, В.Л. Воеводкин // Нефтепромысловое дело. - 2010. - № 7. - С. 4-7.

14. Бетехтин А.Г. Курс минералогии. - М.: КДУ, 2010. $-736 \mathrm{c}$.

15. Ениколопян Н.С., Мхитарян А.А., Карагезян А.С. Сверхбыстрые реакции разложения в твердых телах под давлением // Докл. АН СССР. - 1986. - Т. 288, № 3. - С. 657-660.

16. Кривощеков С.Н., Галкин В.И., Волкова А.С. Разработка вероятностно-статистической методики прогноза нефтегазоносности структур // Нефтепромысловое дело. - 2010. - № 7. - С. 28-31.

17. Рентгенографический количественный фазовый анализ глинистых минералов (каолинита, гидрослюды, монтморилонита): метод. рекомендации № 139 / Научный совет по методам минералогических исследований Всероссийского научно-исследовательского института минерального сырья им. Н.М. Федоровского. - М., 1999.

18. Середин В.В., Хрулев А.С. Изменения температуры образцов горных пород и геоматериалов при их разрушении // Физико-технические проблемы разработки полезных ископаемых. - 2016. - № 4. - С. 63-69.
19. Грунтоведение / В.Т. Трофимов, В.А. Королев, В.А. Вознесенский, Г.А. Голодковская, Ю.К. Васильчук, Р.С. Зиангиров. - М.: Изд-во Моск. гос. ун-та, 2005. - 1024 с.

20. Чиков Б.М., Каргаполов С.А., Ушаков Г.Д. Экспериментальное стресс-преобразование пироксенита // Геология и геофизика. - 1989. - № 6. - С. 75-79.

21. Шлыков В.Г. Использование структурных характеристик глинистых минералов для оценки физико-химических свойств дисперсных грунтов // Геоэкология. - 2000. - № 1. - С. 43-52.

22. Tang L., Sparks D.L. Cation-exchange kinetics on montmorillonite using pressure-jump relaxation // Soil Science Society of America Journal. - 1993. - Vol. 57, № 1. - P. 4246. DOI: $10.2136 /$ sssaj1993.03615995005700010009x

23. Mineralogy of egyptian bentonitic clays ii: geologic origin / M.A. Agha, M.S.A. El Ghar, R.E. Ferrell, G.F. Hart, A. Abdel-Motelib // Clays and clay minerals. 2014. - Vol. 61, № 6. - P. 551-565.

24. Adriaens R., Vandenberghe N., Elsen J. Natural clay-sized glauconite in the neogene deposits of the campine basin (belgium) // Clays and clay minerals. 2014. - Vol. 62, № 1. - P. 35-52.

25. Examining structural and related spectral change in marsrelevant phyllosilicates after experimental impacts between 10-40 gpa / L.R. Friedlander, T.D. Glotch, B.L. Phillips, J.S. Vaughn, J.R. Michalski // Clays and clay minerals. - 2016. - Vol. 64, № 3. - P. 35-52.

26. Ercan H.Ü., Işik Ece Ö., Schroeder P.A., Karacik Z. Differentiating styles of alteration within kaolin-alunite hydrothermal deposits of çanakkale, nw turkey// Clays and clay minerals. - 2016. - Vol. 64, № 3. - P. 245-274.

27. Середин В.В., Ядзинская М.Р. Исследования механизма агрегации частиц в глинистых грунтах при загрязнении их углеводородами // Фундаментальные исследования. - 2014. - № 8-6. - С. 1408-1412.

28. Изучение закономерностей коагуляции глинистых частиц / В.В. Середин, В.И. Каченов, О.С. Ситева, Д.Н. Паглазова // Фундаментальные исследования. - 2013. - № 10-14. - С. 3189-3193.

29. Осовецкий Б.М. Дробная гранулометрия аллювия. - Пермь: Изд-во Перм. ун-та, 1993. - 343 с.

30. Королёв В.А. Моделирование гранулометрического состава лунных грунтов // Инженерная геология. - 2016. - № 5. - С. 40-50.

Please cite this article in English as:

Seredin V.V., Parshina T.Iu. Mass change of bound water in clays under compression. Bulletin of PNRPU. Geology. Oil \& Gas Engineering \& Mining, 2017, vol.16, no.1, pp.23-32. DOI: 10.15593/2224-9923/2017.1.3

Просьба ссылаться на эту статью в русскоязычных источниках следующим образом:

Середин В.В., Паршина Т.Ю. Изменение масс связанной воды в глинах при сжатии // Вестник Пермского национального исследовательского политехнического университета. Геология. Нефтегазовое и горное дело. - 2017. - Т.16, №1. - С.23-32. DOI: $10.15593 / 2224-9923 / 2017.1 .3$ 